half of the Royal Cemetery period. This at least is the inference which Dr. Woolley draws from the number of battle axes, adze-shaped axes and daggers which have been found in this area. An interesting feature in the economy of the city is conjectured to interpret the existence in the very heart of the town of an area which throughout the history of Ur was a mere rubbish heap. A section shows that while this rubbish heap was continually receiving additions, it was at the same time constantly being removed to provide material for the terraces on which new buildings were erected.

\section{Early Art at Giza}

AN interesting account of the excavations of the Egyptian University at Giza during the present season is given by the Cairo correspondent of the Observer in the issue of March 18. The expedition, of which Prof. Selim Hassan is in charge, is engaged in investigating the Fourth Pyramid, with its surroundings, which has been identified as that of Khunt Kawas, daughter of Menkaura of the Fourth Dynasty. The exploration of the city attached to the pyramid, the only one of its kind yet discovered, has been carried further and has resulted in bringing to light, among other discoveries, the source of the water supply of the libation chamber and above the libation tank the tomb of an official described as "the purifier and prophet of the king's daughter". The temple of Khunt Kawas has been located adjoining the temple of Menkaura and has been cleared. The most notable of the finds here are the base of a diorite statue of the king Chephren, grandfather of the princess, and the torso of a sphinx and the body of a statuette of the king which lay in the entrance to the temple of the king. In a temple of Ankhtef, the priest of the king's $K a$, were found two small white limestone statues which are said to be the most perfect examples of the statuesque art of the early period. They represent Ankhtef himself seated and a woman kneeling and kneading bread, which, it is thought, may possibly represent his wife. An almost equally notable specimen of this early art is the statue of a judge of the period, which shows remarkable power in the modelling of the muscles and limbs.

\section{Empire Marketing Board Research Commitments}

WITH the abolition last year of the Empire Marketing Board, considerable anxiety was felt as to the provision for numerous investigations, in progress and projected, hitherto financed by the Board. Some weeks ago, Mr. J. H. Thomas stated in a written reply to a question in the House of Commons that provision was being made for such investigations (NATURE, Feb. 17, p. 254). In reply to a question by Sir Arnold Wilson asking for more specific information, $\mathrm{Mr}$. Malcolm MacDonald has given the following written answer: "The research schemes financed from the Empire Marketing Fund comprise agricultural and scientific research in the United Kingdom and also in the Dominions, India and the Colonies. It has been arranged for 39 of these schemes, representing an annual cost of approximately $£ 200,000$ in all, to be continued, in each case at the same research institution and with the existing personnel. Of these schemes 23 are in the United Kingdom, eight in the Dominions and India and eight in the Colonies. The sum of approximately $£ 115,000$ which is required in the next financial year from United Kingdom funds in respect of these schemes will be charged against Votes administered by various Government Departments in this country. The remaining $£ 85,000$ is being met by the Governments of the Empire or by the institutions or industries concerned."

\section{Research Under the Agricultural Marketing Boards}

IN a written reply to a question by Sir Arnold Wilson in the House of Commons as to what extent the powers conferred by both Agricultural Marketing Acts to adopt schemes for research in the production and marketing of agricultural products have been exercised by the Potato, Bacon, Milk, Pigs, and Hops Marketing Boards, Mr. Walter Elliot, Minister of Agriculture, stated: "The Hops Marketing Board does not possess any powers of the kind referred to. The other Agricultural Marketing Boards mentioned have certain powers which they may exercise in connection with research services, but I understand they have not yet exercised them." Mr. Elliot said he had no doubt that the Boards in question will give attention to the question of research at the earliest possible opportunity, and that they will approach the Ministry of Agriculture should they think the Ministry able to assist them.

\section{Wool Industries Research Association}

The report of the Council of the Wool Industries Research Association for 1933-34 refers to a 40 per cent increase in fees for private investigations as indication of the growing use which is made of the services of the Association by its members. Income from trade subscriptions has slightly increased, but an income of about $£ 2,000$ a year from the Empire Marketing Board has ceased. The activities previously financed by the Board are being continued and efforts are being made to obtain assistance from the Imperial Agricultural Bureaux. At a meeting of the Executive Council of the latter, it was emphasised that the work of the Association at Torridon should be concentrated on investigations of practical value to the grower and to the industrialist, and that Torridon should become a centre from which work on wool utilisation-both as regards research and educational publicity for the Empire as a whole--should emanate. Experiments on the nutritional influences on wool growth have continued in co-operation with the Rowett Research Institute, Aberdeen, and have revealed accentuated differences between a group of sheep fed on a maintenance ration and one receiving a simple supplement of high energy value. Arrangements have been made for further trials of experimental wool packs, including the impregnation of jute packs with rubber latex to anchor the jute fibres so that they do not stray into the wool during transit.

(Continued on $p: 457$. 